\title{
Utilization of $\mathrm{D}-\beta$-Hydroxybutyrate and Oleate as Alternate Energy Fuels in Brain Cell Cultures of Newborn Mice after Hypoxia at Different Glucose Concentrations
}

\author{
E. BOSSI, E. KOHLER, AND N. HERSCHKOWITZ \\ Department of Pediatrics, University of Berne, Switzerland
}

\begin{abstract}
In dissociated whole brain cell cultures from newborn mice, we have previously shown that during glucose deprivation under normoxia, $\mathrm{D}$ - $\beta$-hydroxybutyrate and oleic acid are increasingly used for energy production. We now asked whether this glucose dependency of the utilization of $\mathrm{D}-\beta$-hydroxybutyrate and oleic acid as alternate energy fuels is also present after a hypoxic phase. 3Hydroxy $\left[3-{ }^{14} \mathrm{C}\right]$ butyrate or $\left[\mathrm{U}-{ }^{14} \mathrm{C}\right]$ oleic acid were added to 7- and 14-d-old cultures and ${ }^{14} \mathrm{CO}_{2}$-production compared after hypoxia in normal and glucose-deprived conditions. After hypoxia, the ability of the cells $7 \mathrm{~d}$ in culture to increase $D-\beta$-hydroxybutyrate consumption in response to glucose deprivation is diminished, 14-d-old cells lose this ability. In contrast, after hypoxia, both 7- and 14-d-old cultures maintain or even improve the ability to increase oleate consumption, when glucose is lacking. (Pediatr Res 26: 478-481, 1989)
\end{abstract}

Abbreviations

BOHB, D- $\beta$-hydroxybutyrate

CST, cerebroside-sulfotransferase

Perinatal hypoxia and neonatal hypoglycemia are conditions that can disturb the adaptation of newborns to extrauterine life. Not only glucose, but also ketone bodies and some fatty acids, have been shown to be used for energy production by animal as well as by human brain $(1,2)$. We have chosen dissociated whole brain cell cultures of newborn mice to study the utilization of $\mathrm{BOHB}$ and oleic acid as energy fuels on a cellular level. The cultures consist of oligodendrocytes and astrocytes, and they parallel the in vivo development of myelination in the mouse. After $7 \mathrm{~d}$ of growth, the myelination state of the cultures corresponds to that of human brain at term, after $14 \mathrm{~d}$ to that of human brain at age 6 mo (3). The use of cell cultures makes it possible to investigate directly the metabolic processes of the cells, thus avoiding the influence of the blood-brain barrier and of metabolites originating in an intact organism. With this system we have demonstrated that BOHB and oleic acid can substitute for glucose as cerebral energy fuels in normoxia: both substrates are increasingly converted to $\mathrm{CO}_{2}$ at glucose concentrations below $1 \mathrm{mM}$ (4). Because of the clinically relevant combination

Received September 27, 1988; accepted April 5, 1989.

Correspondence and reprints Emilio Bossi, M.D., Division of Neonatology, Department of Pediatrics, University of Berne, Inselspital, CH-3010 Berne, Switzerland.

Supported by the Swiss National Foundation for Scientific Research Grants 3.945.0.85 and 3.156.0.88. of hypoglycemia with hypoxia, we have now asked whether the cells would maintain this capability also after a hypoxic phase.

\section{MATERIALS AND METHODS}

Animals. Newborn Fuellinsdorf albino mice of timed pregnancies were used. (Hoffmann-La Roche, Basel, Switzerland).

Cell cultivation. A total of $2-16 \mathrm{~h}$ after birth, the mice were decapitated, the whole brain was dissociated by repeated pipetting in Dulbecco's modified Eagle's culture medium, and $7 \times$ $10^{6}$ cells were suspended in $5 \mathrm{~mL}$ medium containing $27 \mathrm{mM}$ glucose in a culture flask. The further steps were carried out according to Wiesmann et al. (5) as described in Reference 4.

Incubation with energy substrates. After 7 or $14 \mathrm{~d}$ of cultivation, the medium was changed, the cultures were rinsed with glucose-free medium, and $5 \mathrm{~mL}$ of Dulbecco's medium containing $20 \mathrm{mM}$ HEPES buffer $\mathrm{pH} 7.4,17 \mu \mathrm{M}$ defatted BSA, and either no glucose or $4 \mathrm{mM}$ D-glucose were added. The latter glucose concentration corresponds to the lower normal blood glucose range, in which no increased utilization of alternate cerebral fuels could be demonstrated (4). In half of the culture flasks of each glucose group, air was bubbled through the medium for $1 \mathrm{~min}$, in the other half, the media were bubbled with $\mathrm{N} 2$. The flasks were then sealed tightly. The N2-bubbled flasks were placed in a plastic box in which air was replaced by N2. Measurements of $\mathrm{PO}_{2}$ in the media with the Roche intravascular $\mathrm{PO}_{2}-$ electrode showed $\mathrm{PO}_{2}$ values of $3-13 \mathrm{~mm} \mathrm{Hg}$ during the whole incubation period. In the normoxic media, $\mathrm{PO}_{2}$ was $134-138$ $\mathrm{mm} \mathrm{Hg}$. After $4 \mathrm{~h}$, the flasks were opened, and medium containing $0.25 \mu \mathrm{Ci}$ of either BOHB- $3^{14} \mathrm{C}$ or of oleic acid- $\mathrm{U}^{14} \mathrm{C}$, without cold substrate, was added into each flask. All media were bubbled with air for $1 \mathrm{~min}$. The flasks were then tightly sealed again and incubated with the radioactive substrates for $3 \mathrm{~h}$. The $\mathrm{CO}_{2}$ produced was trapped on a filter paper moistened with $0.5 \mathrm{~N}$ $\mathrm{NaOH}$, positioned in a plastic center well. The filter papers were counted in $10 \mathrm{~mL}$ Dimilume-30 scintillation fluid.

In preliminary experiments, ${ }^{14} \mathrm{CO}_{2}$ was driven off the medium at the end of incubation, after removal of the original filter paper, by addition of $250 \mu \mathrm{L} 1 \mathrm{~N} \mathrm{HClO}_{4}$. The additional ${ }^{14} \mathrm{CO}_{2}$-activity that could be extracted was consistently between 10 and $20 \%$ and did not depend on $\mathrm{pH}$. Therefore, this acidification step was omitted.

Immunologic identification of cell populations. Indirect immunofluorescence with double staining was used according to the methodology of Bologa-Sandru et al. (6). Antigalactocerebroside antibodies were used for detecting the oligodendrocytes. Astrocytes were stained with anti-GFAP-antibodies according to Bignami et al. (7). No neurons grow in our culture system. These cell identification experiments were performed with cells $14 \mathrm{~d}$ in culture. 
CST activity. CST is a specific enzyme of the myelin-forming oligodendrocytes. Its activity was measured according to Siegrist et al. (8) and expressed per mg protein. The results are given as a percentage of the CST-activity measured at normoxia and 4 $\mathrm{mM}$ glucose.

Lactate was measured by the enzymatic test of Boehringer, Mannheim, West Germany, (Monotest), and glucose by the hexokinase method (Glucoquant, Boehringer).

Expression of the results of ${ }^{14} \mathrm{CO}_{2}$ production. The dpm of ${ }^{14} \mathrm{CO}_{2}$ on the filter paper were related to cell protein as measured by the method of Lowry et al. (9). Relation to DNA [measured according to Hinegardner (10)] yielded similar results. These are, therefore, not presented. Unlabeled $\mathrm{CO}_{2}$ was not measured; therefore, no absolute quantitative indications on substrate utilization can be given.

Statistics. For ${ }^{14} \mathrm{CO}_{2}$ production, the results are given as mean \pm SD. Significance of differences was calculated with the Wilcoxon rank sum test (1\% level of significance). The statistical significance of differences in protein and DNA content as well as of CST activity of cultures was calculated with Student's $t$ test for unpaired data.

Materials and chemicals. The isotopes were from New England Nuclear Co., Boston, MA. They consisted of D- $\beta$-3-hydroxy[3${ }^{14} \mathrm{C}$ ]butyric acid, K-salt, sp act $43-46 \mathrm{mCi} / \mathrm{mmol}$; [U- $\left.{ }^{14} \mathrm{C}\right]$ oleic acid, sp act $900 \mathrm{mCi} / \mathrm{mmol}$. Other chemicals and materials are detailed in Reference 4.

\section{RESULTS}

Effects of hypoxia and of glucose deprivation on the cell cultures. Table 1 shows that hypoxia at $4 \mathrm{mM}$ glucose leads to a significant decrease of protein and DNA concentrations as well as of CST activity in the 7-d-old cultures. Glucose deprivation alone has a similar effect, except for DNA. The combination of glucose deficiency and hypoxia exerts the most significant effects.

Table 2 shows the results for the 14-d-old cultures. At $4 \mathrm{mM}$ glucose, hypoxia leads to a significant lowering of CST activity. Glucose deprivation alone does not significantly affect the cultures. The combination of glucose deficiency and hypoxia significantly decreases protein and DNA content as well as CST activity.

Hypoxia also leads to a marked decrease in the number of oligodendrocytes: in experiments with $4 \mathrm{mM}$ glucose, a mean of 173 cells/60 quadrangles was counted in normoxia (range 148183 ), in hypoxia, there was only a mean of 105 cells (range 93118) left. In experiments without glucose, the number of oligodendrocytes dropped from 211/60 quadrangles (range 206-216) in normoxia to 103 (range 90-116) in hypoxia. Five cultures were stained at each glucose concentration; due to this small number no statistical evaluation was made. Staining could not be performed with cells $7 \mathrm{~d}$ in culture: the cultures, which were not yet completely confluent at this stage, were disrupted by the staining procedure.

Conversion of $\mathrm{BOHB}$ to $\mathrm{CO}_{2}$ (Fig. 1). Glucose deprivation leads to increased $\mathrm{CO}_{2}$ production both in normoxia and after hypoxia, both by cells 7 and $14 \mathrm{~d}$ in culture. When compared to $\mathrm{CO}_{2}$ production in normoxia, the increased $\mathrm{CO}_{2}$ production in glucose deprivation is blunted by hypoxia at $7 \mathrm{~d}$ and abolished at $14 \mathrm{~d}$. Hypoxia alone, without changes in glucose concentration, diminishes $\mathrm{CO}_{2}$ production both in 7- and 14-d-old cells.

Conversion of oleate to $\mathrm{CO}_{2}$ (Fig. 2). Glucose deprivation leads to increased $\mathrm{CO}_{2}$ production both in normoxia and after hypoxia, both by cells 7 and $14 \mathrm{~d}$ in culture. When compared to $\mathrm{CO}_{2}$ production in normoxia, the increased $\mathrm{CO}_{2}$ production in glucose deprivation is slightly increased by hypoxia both at 7 and $14 \mathrm{~d}$. Hypoxia alone, without changes in glucose concentration, does

Table 1. Effect of hypoxia and glucose deprivation on the cells $7 \mathrm{~d}$ in culture*

\begin{tabular}{|c|c|c|c|}
\hline & $\begin{array}{c}\text { Protein } \\
\mathrm{mg} / \text { culture }\end{array}$ & $\begin{array}{c}\text { DNA } \\
\mathrm{mg} / \text { culture }\end{array}$ & $\begin{array}{c}\text { CST-activity } \\
\text { pmol PAPS/h/culture }\end{array}$ \\
\hline $4 \mathrm{mM}$ glucose & $0.72 \mathrm{mg}$ & $0.08 \mathrm{mg}$ & 0.37 \\
\hline $110 \pi$ & $\begin{array}{l}(0.51-0.82) \\
=100 \%\end{array}$ & $\begin{array}{l}(0.07-0.11) \\
=100 \%\end{array}$ & $\begin{array}{l}(0.20-0.56) \\
=100 \%\end{array}$ \\
\hline $\begin{array}{l}4 \text { mM glucose } \\
\text { hypoxia }\end{array}$ & $88 \uparrow$ & $86 \dagger$ & $77 \ddagger$ \\
\hline $\begin{array}{c}0 \text { mM glucose } \\
\text { normoxia }\end{array}$ & $90 \dagger$ & 100 & $86 \S$ \\
\hline $\begin{array}{l}0 \text { mM glucose } \\
\text { hypoxia }\end{array}$ & $79 \ddagger$ & $83 \div$ & $43 \ddagger$ \\
\hline
\end{tabular}

$*$ Results at $4 \mathrm{mM}$ glucose in normoxia given as mean and range $=100 \%$. Remaining data given in percent. Protein and DNA concentrations were measured in 18 cultures, CST activity in 9-17 cultures at each glucose and $\mathrm{O}_{2}$ level.

$\dagger p<0.01, \ddagger p<0.001, \S p<0.02$ as compared with $4 \mathrm{mM}$ glucose at normoxia.

Table 2. Effect of hypoxia and glucose deprivation on the cells $14 \mathrm{~d}$ in culture.*

\begin{tabular}{cccc}
\hline & $\begin{array}{c}\text { Protein } \\
\mathrm{mg} / \text { culture }\end{array}$ & $\begin{array}{c}\text { DNA } \\
\mathrm{mg} / \text { culture }\end{array}$ & $\begin{array}{c}\text { CST-activity } \\
\text { pmol PAPS/h/culture }\end{array}$ \\
\hline 4 mM glucose & 1.50 & 0.14 & 0.57 \\
normoxia & $(0.29-1.89)$ & $(0.11-0.20)$ & $(0.38-0.85)$ \\
$=100 \%$ & $56^{*}$ \\
4 mM glucose & $=100 \%$ & $9100 \%$ & 87 \\
$\begin{array}{c}\text { hypoxia } \\
\text { mM glucose } \\
\text { normoxia } \\
0 \text { mM glucose } \\
\text { hypoxia }\end{array}$ & 95 & 100 & $15 \ddagger$ \\
\hline
\end{tabular}

\footnotetext{
* Protein and DNA concentrations were measured in 44-59, CST activity in 14-24 cultures at each glucose and $\mathrm{O}_{2}$ level $p<0.01, \uparrow p<0.02, \ddagger p$
} $<0.001$ as compared with $4 \mathrm{mM}$ glucose at normoxia. 


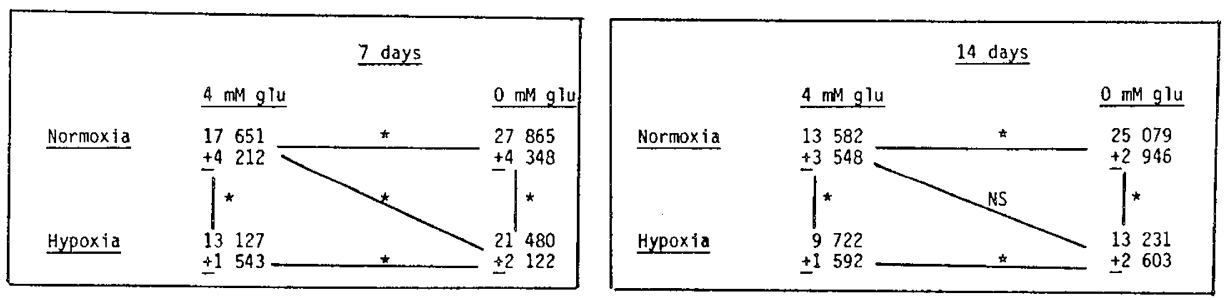

Fig. 1. Conversion of $\mathrm{D}-\beta$-hydroxy + butyrate- $3-{ }^{14} \mathrm{C}$ to ${ }^{14} \mathrm{CO}_{2}$ by cells 7 and 14 days in culture at different glucose concentrations and during constant normoxia or after hypoxia. dpm ${ }^{14} \mathrm{CO}_{2} / \mathrm{mg}$ protein $\pm \mathrm{SD}$; ${ }^{*}$ Difference significant at the $1 \%$ level. A total of 15 to 25 cultures per point.

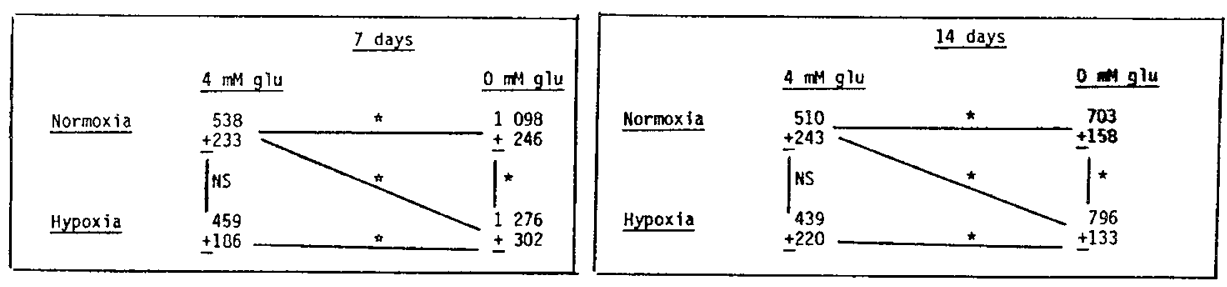

Fig. 2. Conversion of oleic acid- $U-{ }^{14} \mathrm{C}$ to ${ }^{14} \mathrm{CO}_{2}$ by cells 7 and 14 days in culture at different glucose concentrations and during constant normoxia or after hypoxia. dpm ${ }^{14} \mathrm{CO}_{2} / \mathrm{mg}$ protein $\pm \mathrm{SD}$. * Difference significant at the $1 \%$ level. A total of 23 to 51 cultures per point.

not modify $\mathrm{CO}_{2}$ production significantly in the presence of 4 $\mathrm{mM}$ glucose, at 7 or $14 \mathrm{~d}$. At $0 \mathrm{mM}$ glucose, $\mathrm{CO}_{2}$ production is slightly but significantly increased by hypoxia both at 7 and 14 d.

Influence of $\mathrm{pH}$ and lactate on conversion of substrates to $\mathrm{CO}_{2}$. In normoxia, the $\mathrm{pH}$ measured in the media at the end of the incubations ranged from 7.30 to 7.40 . The lower values of this range were found in the media containing glucose. After hypoxia, $\mathrm{pH}$ ranged from 7.15 to 7.25 . Again, the lower values were found in the media containing glucose. The values remained in these ranges until the end of the incubations, after the media had again been made normoxic.

Lactate concentrations in the media increased from a range of $0.17-0.25 \mathrm{mmol} / \mathrm{L}$ at 0 glucose and normoxia to a range of 2.28-3.20 at $4 \mathrm{mM}$ glucose and hypoxia in 7-d-old cultures, and from $1.35-1.75$ to $6.20-7.46 \mathrm{mmol} / \mathrm{L}$ under corresponding conditions in 14-d-old cultures.

This raised the question of whether the observed effects of different glucose concentrations and of hypoxia on the conversion of $\mathrm{BOHB}$ and oleate to $\mathrm{CO}_{2}$ could be due to changes in $\mathrm{pH}$ and lactate. To answer these questions, $\mathrm{pH}$ values and lactate concentrations were altered. Normoxic experiments were carried out at $\mathrm{pH}$ ranges found in hypoxia and hypoxic experiments at $\mathrm{pH}$ values measured in normoxia. This was achieved by modifying the composition of the HEPES buffer. By adding exogenous lactate, normoxic experiments were carried out at lactate ranges found in hypoxia. These manipulations did not alter the $\mathrm{CO}_{2}$ production. Thus, $\mathrm{pH}$ and lactate levels similar to those after hypoxia did not modify $\mathrm{CO}_{2}$ production when applied in normoxia. Furthermore, in our system, the amount of ${ }^{14} \mathrm{CO}_{2}$ remaining in the medium after incubation was not dependent on $\mathrm{pH}$. $\mathrm{pH}$ and lactate differences between normoxia and hypoxia are, therefore, not responsible for the observed differences in $\mathrm{CO}_{2}$ production.

\section{DISCUSSION}

The goal of these experiments was to investigate the effects of hypoxia on the ability of developing glial cells to use BOHB and oleate as alternate energy fuels for glucose. Previously reported results (4) were confirmed: in normoxia, glucose deprivation leads to increased utilization of both substrates. The results are in agreement with the elevated activities of cerebral ketone-bodymetabolizing enzymes found in suckling as compared to adult rats (11). In the human infant, cerebral ketone body utilization is also inversely related to postnatal age (1). In our experiments, the younger cells produce more ${ }^{14} \mathrm{CO}_{2} / \mathrm{mg}$ protein than the older ones. Similar data on oleic acid utilization have not been described in the literature. The results are in contrast to recent experiments carried out by MR-spectroscopy (12): In newborn rat brain, insulin-induced hypoglycemia did not modify fatty acid and $\mathrm{BOHB}$ levels. The glucose concentration reached in these experiments, however, was $2.1 \mathrm{mM}$. This might not be sufficient to elicit the utilization of alternate energy fuels. In our earlier experiments, increased utilization of both BOHB and oleate occurred only below glucose concentrations of 0.5 and 1 $\mathrm{mM}$, respectively (4).

Hypoxia was induced by exposing the cultures to N2. In the medium, $\mathrm{PO}_{2}$-values of 3 to $13 \mathrm{~mm} \mathrm{Hg}$ were reached. The increase in lactate and the drop in $\mathrm{pH}$ show that the level of hypoxia reached influenced the cellular glycolytic metabolism and modified substrate availability for energy production in the Krebs cycle.

Hypoxia influences the utilization of BOHB and oleate under glucose deprivation in different ways. The increased conversion of $\mathrm{BOHB}$ to $\mathrm{CO}_{2}$ in glucose deprivation is blunted by hypoxia in cells $7 \mathrm{~d}$ in culture and abolished in the cells $14 \mathrm{~d}$ in culture. In contrast, the increased conversion of oleate to $\mathrm{CO}_{2}$ in glucose deprivation is further accentuated by hypoxia both in 7-d as well as in 14-d-old cells. In the presence of $4 \mathrm{mM}$ glucose, hypoxia significantly diminishes $\mathrm{CO}_{2}$ production from $\mathrm{BOHB}$. The $\mathrm{CO}_{2}$ production from oleate, however, is not significantly diminished by hypoxia in the presence of $4 \mathrm{mM}$ glucose.

According to these results, oleate consumption as alternate cerebral energy fuel appears to be stimulated after hypoxia, whereas BOHB consumption is impaired when compared to normoxia. We cannot explain this finding. It is not due to variations in $\mathrm{pH}$, since modifications in the range of 7.0 to 7.5 did not influence the results. In children with glycogenosis due to glucose-6-phosphatase deficiency, Fernandes et al. (13) have shown that lactate and not $\mathrm{BOHB}$ is the principal cerebral energy fuel. In newborn rat brain slices incubated in $100 \%$ oxygen, lactate is also a major energy fuel (14). In our neonatal mouse brain cell cultures incubated in normoxia, however, the addition of lactate did not alter $\mathrm{CO}_{2}$ production. Lactate, therefore, is not preferred to BOHB and oleic acid in our study model. Due to the different systems and experimental designs, our data cannot be compared directly to other results. 
Furthermore, because the addition of lactate did not influence $\mathrm{CO}_{2}$ production, the stimulation of oleate consumption after hypoxia cannot be explained by the elevated lactate concentrations either. Oleate could be the first and more easily available energy substrate when glucose is lacking after hypoxia, because it is a cell component and its uptake is not dependent on ATP. In contrast, $\mathrm{BOHB}$ is not part of the cell structure, is water soluble, and dependent on ATP for its uptake.

Conclusions as to the quantitative importance of oleate utilization cannot be drawn from our results, because unlabeled $\mathrm{CO}_{2}$ was not measured and the specific activities of the substrates reaching the cells were not controlled. Despite the fact that the same amount of $\mu \mathrm{Ci}$ of oleate $-{ }^{14} \mathrm{C}$ and $\mathrm{BOHB}-{ }^{14} \mathrm{C}$ were added and that the specific activity of oleate was higher, it yielded less ${ }^{14} \mathrm{CO}_{2}$ counts than $\mathrm{BOHB}-{ }^{14} \mathrm{CO}_{2}$. This difference may be due to the fact that BSA was present in the media and binds oleate. Also, dilution of oleate- ${ }^{14} \mathrm{C}$ by cold oleate originating from the cell membrane could occur.

The effects of hypoxia, hypoglycemia, and the combination of both on energy metabolism of the intact mammalian brain have been studied by magnetic resonance: ${ }^{31} \mathrm{P}$-magnetic resonancespectroscopy of adult guinea-pig brain tissue showed a decrease in the phosphocreatine content at $0.2 \mathrm{mM}$ glucose in the superfusing medium under normoxia, and at $0.5 \mathrm{mM}$ glucose under hypoxia (15). Insulin-induced hypoglycemia or hypoxic hypoxia induced a decrease in the phosphocreatine peak coincident with an increase of the inorganic phosphorus peak in the brain of adult rabbits. The behavior of the phosphodiester peak in hypoglycemia suggested the generation of energy from alternate sources (16). Our results show that BOHB and oleate are used as energy fuels by glial cells also after hypoxia. The differences between the 7- and the 14-d-old glial cells raise the speculative question, whether, in hypoxia, the brain of the human term newborn (corresponding to 7-d-old cultures) as well as the brain of the 6-mo-old infant (corresponding to 14-d-old cultures) rely on oleate as alternate energy fuel for glucose, whereas the capacity of using $\mathrm{BOHB}$ in glucose deprivation is diminished in the newborn and completely lost at 6 mo under hypoxic conditions. However, as stated earlier, no quantitative conclusions can be drawn from this study. In our system, hypoxia and glucose deprivation induce either an unknown metabolic switch or a modification of uptake of oleate and/or BOHB.
Acknowledgment. The authors wish to thank Dr. M. Schüpbach, Department of Mathematical Statistics, University of Berne, for his statistical advice.

\section{REFERENCES}

1. Kraus H, Schlenker S, Schwedesky D 1974 Developmental changes of cerebral ketone body utilization in human infants. Hoppe Seyler's Z. Physiol Chem 335:164-170

2. Roux J, Yoshioka I, Myers RE 1970 Conversion of palmitate to respiratory carbon dioxide by foetal tissue of man and monkey. Nature 227:963-964

3. Herschkowitz N, Wiesmann U, Siegrist HP, Sandru L, Zuppinger K, Bossi E, Hofmann K, Schäfer R, Beranek C 1980 Pathogenetische Untersuchungen zur abnormen Gehirnentwicklung in Hirnzellkulturen. Schweiz Rundschau Med (PRAXIS) 69:1205-1210

4. Bossi E, Zuppinger K, Siegrist HP, Wiesmann U, Herschkowitz N 1982 Agedependent utilization of D-Beta-OH-Butyrate and oleic acid as glucose substitutes by neonatal mouse brain cell cultures. Pediatr Res 16:579-582

5. Wiesmann U, Hofmann K, Burkart T, Herschowitz N 1975 Dissociated cultures of newborn mouse brain. I. Metabolism of sulfated lipids and mucopolysaccharides. Neurobiology 5:305-315

6. Bologa-Sandru L, Siegrist HP, Z'Graggen A, Hofmann K, Wiesmann U, Dahl D, Herschkowitz N 1981 Expression of antigenic markers during the development of oligodendrocytes in mouse brain cell cultures. Brain Res 210:217229

7. Bignami A, Eng LF, Dahl D, Uyeda CT 1972 Localization of the glial fibrillary acidic protein in astrocytes by immunfluorescence. Brain Res 43:429-435

8. Siegrist HP, Burkart T, Steck A, Wiesmann U, Herschkowitz N 1976 Influence of lipids on the activity of cerebroside-sulfotransferase in mouse brain: a comparative study of jimpy and normal mouse brains. J Neurochem 22: 599-604

9. Lowry OH, Rosebrough NJ, Farr AL, Randall LJ 1951 Protein measurement with the Folin phenol reagent. J Biol Chem 193:265-275

10. Hinegardner RT 1971 An improved fluorometric assay for DNA. Anal Biochem 39:197-201

11. Page MA, Krebs HA, Williamson DH 1971 Activities of enzymes of ketonebody utilization in brain and other tissues of sucking rats. Biochem J 121:4953

12. Young RSK, Petroff OAC, Dunham SL, Cowan BE 1987 Brain metabolism during neonatal hypoglycemia: in vivo ${ }^{31} \mathrm{P}$ and in vitro ${ }^{1} \mathrm{H}$ NMR-studies. Proceedings Sixth Annual Meeting of the Society of Magnetic Resonance in Medicine, p 532(abstr)

13. Fernandes J, Berger R, Smith GPA 1984 Lactate as cerebral metabolic fuel for glucose-6-phosphatase deficient children. Pediatr Res 18:335-339

14. Fernandez E, Medina JM 1986 Lactate utilization by the neonatal rat brain in vitro. Competition with glucose and 3-hydroxybutyrate. Biochem J 234:489492

15. Cox DWG, Morris PG, Feeney J, Bachelard HS $1983{ }^{31} \mathrm{P}-\mathrm{NMR}$ studies on cerebral energy metabolism under conditions on hypoglycaemia and hypoxia in vitro. Biochem $\mathbf{J} 212: 365-370$

16. Prichard JW, Alger JR, Behar KL, Petroff OCA, Shulman RG 1983 Cerebral metabolic studies in vivo by ${ }^{31}$ P-NMR. Proc Natl Acad Sci USA 80:27482751 